\title{
Recommendations for The Diagnosis and Management of Osteoporosis: A Local Perspective
}

\author{
The Osteoporosis Working Group, King Faisal Specialist Hospital and Research Center
}

Hussein Raef, MD, FACP, FACE*; Husn H. Frayha, MD, FRCPC†; Mohamed El-Shaker, MD‡; Abdulla Al-Humaidan, PharmD**; Walter Conca,MD*; Ulla Sieck, MDף; Janine Okane, MD¥

$\mathrm{T}$ he subject of postmenopausal osteoporosis continues to be an important one for clinicians and epidemiologists, as the incidence of osteoporotic fracture continues to increase and the burden of such fractures on the health economy is expected to rise to astonishing figures. In the United States alone, 1.5 million osteoporotic fractures occur annually, with estimated direct expenditures of over $\$ 14$ billion (American Association Of Clinical Endocrinologists guidelines). In the United Kingdom, 200000 fractures per year are attributed to osteoporosis at an annual cost of over $£ 940$ million (Royal College Of Physicians guidelines). In Asia, the projected number of hip fractures is 3 million in the year 2050. ${ }^{1}$ Although these costs are considerable, the price of prevention and treatment for osteoporosis could be as high. Therefore, recommendations and guidelines for detection, screening, prevention and management of osteoporosis are obviously needed.

A recent report by The US Preventive Services Task Force based on a review of evidence found that there is good reason for screening women for osteoporosis at age 65 and above, or between age 60 to 64 in the presence of significant fracture risk factors. This recommendation is in contrast to a previous recommendation made by the same task force against routine screening in 1997. Still there are no recommendations by the task force on screening younger postmenopausal women. ${ }^{2}$ A year 2000 consensus conference by NIH noted that the value of universal screening was not yet established. The National Osteoporosis Foundation and the American Association of Clinical Endocrinologists have made more liberal recommendations.

Guidelines for prevention and treatment can also be controversial, especially when it comes to the level of bone mineral density (BMD) at which one would initiate prevention or treatment measures with pharmacological agents. Recent studies ${ }^{3,4}$ have shown an unexpected increased risk of cardiovascular events in postmenopausal women with the use of hormone replacement therapy (HRT). In addition, there was an increase in the risk of breast cancer and venous thrombosis. HRT has been regarded as a cornerstone, and often a first-line therapy, together with calcium, in the prevention and treatment of postmenopausal osteoporosis. Many women used this agent with the idea that it would also decrease cardiovascular risks. But the above
From the Departments of ${ }^{*}$ Medicine, tPediatrics, $¥$ Family Medicine and Polyclinics, **Pharmacy, and MObstetrics and Gynecology, King Faisal Specialist Hospital \& Research Center Riyadh, Saudi Arabia

Correspondence to:

Dr. Hussein Raef

Department of Medicine, $M B C 46$

King Faisal Specialist Hospital \& Research Centre

P.O. Box 3354

Riyadh 11211

Kingdom of Saudi Arabia

Email: hraef@kfshrc.edu.sa

Accepted for publication: April 2004

findings have made it difficult to use HRT without accepting the risks involved. The value of newer pharmacological agents like bisphosphonates and selective estrogen receptor modulators (SERMs) have been established in treating postmenopausal osteoporosis, but their role in fracture prevention for subjects who are not osteoporotic has not been proven, although such therapy may prevent bone loss and improve BMD. ${ }^{5}$

It is clear therefore that practitioners need guidelines and recommendations for a rational and evidence-based approach to this problem. Such guidelines or recommendations should ideally be based on studies and projections made in the same population where these recommendation would be applied. Some of the factors that would influence these guidelines in a certain population are: 1) the incidence and the medical and financial impact of osteoporotic fractures in this population, 2) the prevalence of osteoporosis, especially among postmenopausal women, 3) the priority of osteoporosis compared to other public health issues in that society, 4) the cost-effectiveness of diagnostic, preventive and treatment measures, and 5) lifestyle factors and conditions that might impact the quality of bone or the risk of fracture in the young, postmenopausal women, and in the elderly (e.g., sun exposure, exercise, level of physical activity, chance of falling).

Data on the prevalence of osteoporosis, rates of verte- 
bral and hip fractures, and the correlation of BMD and other fracture risk factors with fracture rates is generally sparse or lacking for Saudi Arabia, Gulf countries, and other Middle Eastern Arab countries. Nevertheless, certain deductions can be made from the available studies and personal observations: 1) BMDs are generally lower in the population of this region compared with the western population, with a higher percentage of young subjects and premenopausal women with osteopenia. ${ }^{6}$ However, a correlation between BMD and fracture rates has not been established in this region. 2) Fracture rates are lower than those reported in the west, but more than those reported in the Far East. ${ }^{7.8}$ Thus, using BMD parameters alone will likely result in unnecessary treatment and might not be cost effective. 3) Vitamin D deficiency is still a common problem in this region.

There is an obvious need for local guidelines based on local data and experience. Local guidelines are not intended to replace the individual judgment needed for best use of the evidence while taking in account local and cultural factors. The recommendations in this document are based on a vast amount of published literature and consensus guidelines on the diagnosis, prevention, and management of osteoporosis. Also, it took into account local considerations. These recommendations are subject to change pursuant to the following: 1) medical judgment relative to individual patient needs, 2) availability of data on the epidemiology of osteoporosis and osteoporosis-related fractures, and appropriate reference ranges of bone mineral density in Saudi Arabia; 3) availability of new diagnostic strategies and therapies for prevention and treatment of osteoporosis, as well as cost-effectiveness studies, and 4) a definition of the priority of osteoporosis compared to other public health conditions in this country.

\section{Definition of osteoporosis}

Osteoporosis is a progressive systemic skeletal disorder characterized by low bone mass and micro-architectural deterioration of bone tissue, with a consequent increase in bone fragility and susceptibility to fracture (NIH Consensus Statement). A fragility fracture is one that occurs as a result of either an injury that is insufficient to fracture normal bone, or as a result of no identifiable trauma (Canadian guidelines). Osteoporosis is a function of bone mass achieved at maturity and subsequent bone loss that is accentuated in the early postmenopausal period, and is influenced by certain risk factors.

\section{Osteopenia/osteoporosis and fractures in the region}

Local and regional information about osteoporosis and fracture rates is sparse. In a study of 483 postmenopausal Saudi women 52 to 62 years of age, Al Desouki found the rate of osteopenia and osteoporosis to be $34 \%$ and $24 \%$, respectively. ${ }^{10}$ In another study by $\mathrm{Al}$ Ghannam et al of 321 healthy Saudi women, the prevalence of osteoporosis was
$3.2 \%$ for the 31 - to 40 -year age group, $5.9 \%$ for the 41 - to 50 -year age group, and $28 \%$ for the $>50$-year age group. The prevalence of osteopenia in the respective age groups was $38 \%, 38 \%$, and $66 \%$. Severe vitamin D deficiency was present in $52 \%$ of the subjects. ${ }^{11}$ BMD in healthy Saudi females is significantly lower than in their western counterparts. This may be due in part to the prevalent vitamin $\mathrm{D}$ deficiency. Vitamin D deficiency may cause osteomalacia and affect the BMD measurement. Correction of the deficiency can result in improvement of BMD.

There are also limited data on fracture rates in the region. In a study from Lebanon, Baddourah et al found the lifetime risk for all fractures to be $9.3 \%$ in males, and $16.7 \%$ in females. ${ }^{7}$ This rate is higher than other Asian countries, but less than Europe. In Kuwait, Memon et al found hip fracture age-standardized annual rates of 29.5/100 000 in females, and 20/100 000 in males. ${ }^{12}$ These rates are also higher than what has been reported form other Asian countries. Al-Nuaim et al estimated the incidence of proximal femur fractures for women per 100,000 population to be 4.5 in the 40- to 49-year age group, 14.6 for the 50- to 59-year age group, 79 for the 60- to 69-year age group, and 394 for the $>70$-year age group. The respective rates for men were 7,22 , 36 and $251 .{ }^{8}$ The higher incidence of fractures in males compared to females in the age group 40- to 59-year age group is believed to be due to lifestyle factors and involvement in activities that may lead to fractures. It is generally believed that fracture rates in the Saudi population are less than what has been reported from the West. This might be related to genetic factors that may influence bone quality, or cultural and lifestyle differences.

\section{Clinical manifestations and complications}

Osteoporosis is a silent disease, as bone loss occurs without symptoms. Most of the time there are no warning signs until a fragility fracture occurs. Osteoporosis-related fractures may occur in any bone but are most likely to occur at sites of low bone mass. The most typical sites of osteoporosis related fractures are the vertebrae, distal radius, proximal femur, and ribs.

The morbidity of osteoporosis comes mainly from fractures and their potential complications. Vertebral compression fractures are associated with pain, deformity, disability, and increased mortality. ${ }^{13}$ The most serious consequences, however, are those associated with hip fractures. In one study on elderly subjects who sustained hip fractures, the life expectancy was reduced by 1.8 years or $25 \%$ compared to a matched population. There was also a significant increase in morbidity and health costs in those who had hip fracture. ${ }^{14}$

\section{Evaluation/diagnosis}

Optimal evaluation consists of establishing the diagnosis of osteoporosis on the basis of bone mass assessment, es- 
Table 1. World Health Organization operational definition of osteoporosis ( WHO Technical Report Series 843, 1994).

\begin{tabular}{ll}
\hline Definition & Criteria \\
\hline Normal & BMD within -1 SD of reference mean for young adults \\
\hline Low bone mass (osteopenia) & BMD within -1.0 and -2.5 SD from reference mean for young adults \\
Osteoporosis & BMD less than -2.5 SD from reference mean for young adults \\
Severe & Osteoporosis as defined above with one or more fragility fractures \\
\hline
\end{tabular}

$\mathrm{BMD}=$ bone mineral density, $\mathrm{SD}=$ standard deviation.

Table 2. Variables and risk factors of the FRACTURE INDEX and associated score.

\begin{tabular}{|c|c|}
\hline Variable/Risk Factor & Score \\
\hline \multicolumn{2}{|l|}{ Age Group (years) } \\
\hline Less than 65 & 0 \\
\hline $65-69$ & 1 \\
\hline $70-74$ & 2 \\
\hline $75-79$ & 3 \\
\hline $80-84$ & 4 \\
\hline More than 85 & 5 \\
\hline Fracture after age 50 years & 1 \\
\hline Maternal hip fracture after age 50 years & 1 \\
\hline Weight less than $57 \mathrm{~kg}$ & 1 \\
\hline Current smoker & 1 \\
\hline Uses arms to stand from chair & 2 \\
\hline \multicolumn{2}{|l|}{ Hip BMD (T- score) if done } \\
\hline More than -1 & 0 \\
\hline-1 to -2 & 2 \\
\hline-2 to -2.5 & 3 \\
\hline Less than -2.5 & 4 \\
\hline
\end{tabular}

Adapted from Black D, Steinbuch M, Palermo L, et al, An Assessment Tool for Predicting Risk in Postmenopausal Women, Osteoporosis International 2001; 12:519-528.

tablishing the fracture risk, and determining the need for instituting therapy. Bone strength is related to the density and quality of bone. There is at present no accurate measure for bone quality. BMD is considered a surrogate measure of bone strength. Dual-energy $\mathrm{x}$-ray absorptiometry (DXA) is the preferred technique to measure $\mathrm{BMD}$, and is the technique used at most centers. Quantitative ultrasound is useful for screening for osteoporosis.

The hip is the preferred site for BMD measurement due to the high predictive value of hip BMD for fracture risk, particularly in the elderly. ${ }^{15}$ BMD measurement at the spine predicts spine fracture better than measurements at other sites. However, spine changes may affect BMD measurement. The World Health Organization (WHO) has established an operational definition for osteoporosis based on BMD as measured by DXA, commonly expressed as a T-score (Table 1).

A history and a physical examination to evaluate fracture risks should include assessment for loss of height and change in posture. Laboratory evaluation for secondary causes of osteoporosis should be considered when osteoporosis is diagnosed. Serum calcium, phosphorus, creatinine, vitamin $D$, a complete blood count and thyroid stimulating hormone (TSH) levels are usually sufficient baseline tests. Further laboratory tests can be done as clinically appropriate, such as parathyroid hormone level, urine free cortisol, liver function tests, or serum immune electrophoresis.

Biochemical indices of skeletal turnover could potentially be helpful in the diagnosis and monitoring of therapy. However, as their role has not been fully elucidated, they are not yet recommended in routine clinical management. The decline in bone resorption markers in response to antiresorptive therapy occurs before a significant change in $\mathrm{BMD}$, which may explain the decrease in fracture rates seen early with such therapy, before changes in BMD. ${ }^{16}$ 


\section{Fracture risk factors and fracture index}

The FRACTURE Index is a simple clinical tool that was found to be helpful in assessing the risk of hip, vertebral and non-vertebral osteoporotic fractures in elderly postmenopausal women with and without BMD T-scores. ${ }^{9}$ The FRACTURE Index comprises several variables/risk factors. These variables and the score associated with each variable are summarized in Table 2. Subjects with a score of 4 without $\mathrm{BMD}$, or 6 with $\mathrm{BMD}$ are candidates for screening, prevention or treatment as appropriate. These risk factors could also be useful in assessing the risk of osteoporotic fractures in elderly men. ${ }^{17}$ This scoring system has however not been evaluated in secondary osteoporosis or steroid-induced osteoporosis.

\section{Indications for BMD measurement}

Some international guidelines for osteoporosis screening recommend BMD testing for all women age 65 years or older, and for postmenopausal women under the age of 65 years (especially, 60-64 years) who have one or more additional high risk factors for osteoporosis. ${ }^{2}$ However, as the BMD is generally lower in Saudi women compared to their western counterparts, they may develop osteoporosis and fractures at an earlier age. It is also relevant that physical activity, and therefore the risk of falling, may be less in elderly females older than 65 years, according to local cultural habits. Thus, it is reasonable to start screening postmenopausal Saudi women at an earlier age than that recommended for western women. We stress that BMD measurement should only be done if it will influence management decisions. We recommend BMD measurement in the situations described in Table 3.

\section{Prevention}

Prevention is the most important measure in addressing low BMDs in the youth and in women during reproductive age. Frequent pregnancies and lactation may predispose women in our society to lower BMDs. Thus, proper nutritional and family planning advices are warranted for this group of women. Another important target for prevention is postmenopausal women and those with conditions predisposing to osteoporosis.

Initiatives to prevent osteoporosis should include the following measures:

- Optimal nutrition in youth to achieve high peak bone mass, including adequate intake of calcium and Vitamin $\mathrm{D}$

- Regular weight bearing exercise

- Identification and treatment of subjects with Vitamin D deficiency, especially in children, females in the reproductive age group, and the elderly

- Avoidance of tobacco smoking and excessive alcohol intake

- Assessment of every postmenopausal woman for risk of osteoporosis to determine the need for diagnostic tests and prevention/treatment

- Early treatment of secondary causes of osteoporosis (e.g., thyrotoxicosis, smoking, primary hyperparathyroidism, other secondary causes)

- Prevention and early treatment of osteoporosis in patients who are receiving high-dose steroid therapy, or other drugs that may contribute to osteoporosis

The value of antiresorptive agents for fracture prevention has not been proven for those with no prior fractures, or with BMD greater than -2.5 standard deviations from the reference mean, although such agents might improve or stabilize BMD. 5 Therefore, their use should be limited to those with history of fractures or with multiple risk factors for fractures.

\section{Management}

Important goals in the management of osteoporosis are to prevent fractures, treat pain and discomfort caused by osteoporosis complications, and improve bone density/quality, if possible. Non-pharmacological measures to manage osteoporosis include changing adjustable lifestyle risk factors, preventing falls, maintaining or improving mobility, and increasing weightbearing exercises. Pharmacological measures include treating secondary causes of osteoporosis, and associated disorders, treating pain, discomfort and other associated morbidity, and increasing bone mass. Drugs for osteoporosis primarily reduce bone turnover by inhibiting osteoclast activity. Although they may lead to an early increase in bone mass, the drugs mainly prevent further loss of bone. Agents that primarily increase bone formation (e.g. parathyroid hormone) have only recently become available.

\section{Classes of drugs available for prevention and treatment of osteoporosis (See APPENDIX I and II)}

\section{Calcium and Vitamin D supplementation}

These agents are not sufficient as a sole treatment of osteoporosis, but rather as adjuncts to therapy. They are however essential in any prevention or treatment plans. Calcium and vitamin D decrease bone loss in postmenopausal women, and may reduce the risk of vertebral fractures and possibly non-vertebral fractures, especially in the elderly and in subjects with low calcium and vitamin D. A recent meta-analysis of the effect of calcium and vitamin $\mathrm{D}$ showed only an effect of vitamin $\mathrm{D}$ in decreasing vertebral fractures. ${ }^{18-20}$

The recommendation for adequate daily calcium intake, and available products are summarized in Appendix I. For most patients with osteoporosis, diet alone does not provide adequate calcium intake and, therefore, calcium supplementation is necessary. Calcium supplements are better taken with meals. No more than $500 \mathrm{mg}$ of elemental calcium should be taken at a time since excess calcium may not be absorbed as effi- 
Table 3. Recommendations for bone mineral density measurement.

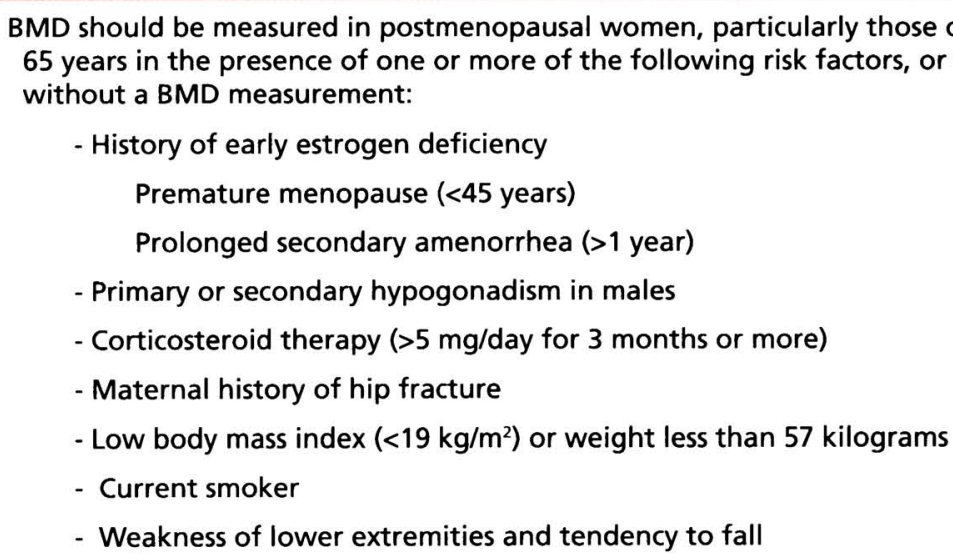

BMD should be measured in the presence of disorders associated with osteoporosis, when a BMD assessment is helpful in the management decision of the disease or in the treatment of suspected osteoporosis:

- Anorexia nervosa

- Malabsorption syndrome

- Primary hyperparathyroidism

- Post-transplantation

- Chronic renal failure

- Hyperthyroidism

- Prolonged immobilization

- Cushing's syndrome

- Chronic anticonvulsant therapy

- Chronic heparin therapy

BMD should be measured when there is radiographic evidence of osteopenia and/or vertebral deformity, loss of height, or thoracic kyphosis.

BMD should be measured in the presence of fragility fracture, particularly of the hip, spine or wrist, especially after age $\mathbf{4 0}$ years.

$\mathrm{BMD}$ can be measured in monitoring treatment

ciently. Calcium should not be taken at the same time as iron supplements as the absorption of both products may be adversely affected when given concurrently. The recommended total daily intake of vitamin $\mathrm{D}$ is $400 \mathrm{IU}$ for men and women under 50 years, and $800 \mathrm{IU}$ for men and women 50 years. An alternative to supplementation is exposure to the sun for 10 to 15 minutes every day, 2 to 3 times/week.

\section{Hormone replacement therapy (HRT)}

HRT improves BMD in postmenopausal women. ${ }^{21}$ Most of the studies however on the effect of HRT in fracture prevention were retrospective and not well designed. The recent Women's Health Initiative (WHI) prospective study did however indicate an effect in decreasing the risk of vertebral and non-vertebral fractures, including hip fractures. ${ }^{3,22}$

HRT has been used widely for prevention and treatment of osteoporosis in postmenopausal women. The WHI study ${ }^{3}$ showed an increased risk of invasive breast cancer, coronary artery disease, venous thromboembolism (pulmonary, deep vein), and stroke in healthy postmenopausal women who received a daily dosing regimen of $0.625 \mathrm{mg}$ of conjugated equine estrogen (Premarin) plus $2.5 \mathrm{mg}$ of medroxyprogesterone acetate (Provera) compared to women who received placebo. These results call for caution. When HRT is used for osteoporosis prevention and treatment, women and their physicians should weigh the benefits of long-term HRT against the subject's personal risks for coronary artery disease, stroke, venous thromboembolic disease, and breast cancer. These results may not apply to other forms of estrogen replacement, but caution is warranted. Additionally, the WHI group states the following in relation to estrogen plus progestin use: "while short term use was not studied, women taking the therapy for relief of postmenopausal symptoms may reap more benefits than risks." At this point however, 
Table 4. Summary of effects of pharmacological agents on bone mineral density and fracture risk according to randomized, controlled trials.

\begin{tabular}{|c|c|c|c|c|}
\hline Agent(s) & BMD & Hip fractures & $\begin{array}{l}\text { Vertebral } \\
\text { fractures }\end{array}$ & Other Fractures \\
\hline \multicolumn{5}{|c|}{ Alendronate/risedronate } \\
\hline Calcitonin & & N/D & & $N / D$ \\
\hline Calcitriol & & $N / D$ & & \\
\hline Calcium & & N/D & & $N / D$ \\
\hline \multicolumn{5}{|c|}{ Hormone replacement therapy } \\
\hline Raloxifene & & $N / D$ & & $N / D$ \\
\hline
\end{tabular}

N/D: Not demonstrated (No effect demonstrated, or evidence is not conclusive).

Table 5. Recommendations for treatment of osteoporosis.

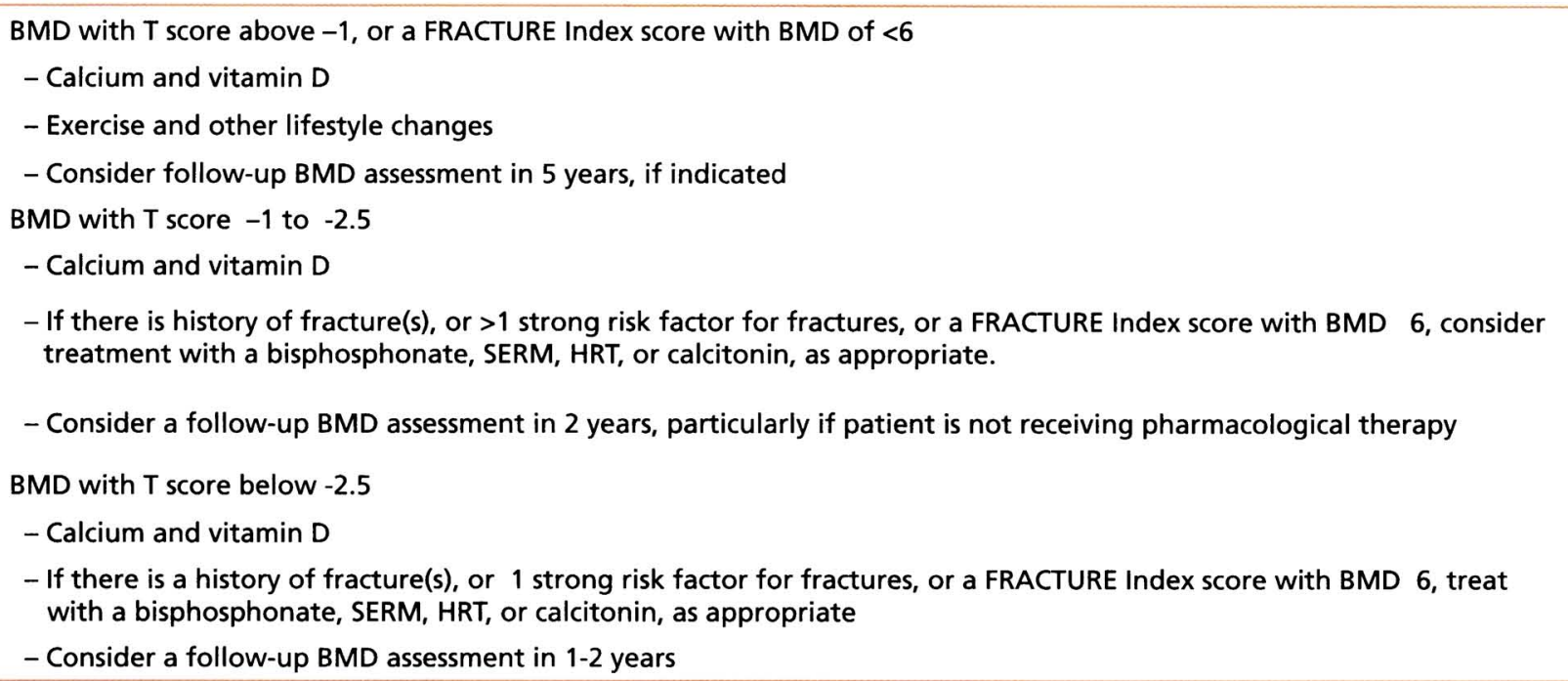

we do not recommend the routine use of classical estrogen replacement therapy for the sole purpose of prevention or treatment of osteoporosis.

\section{Bisphosphonates (e.g., alendronate, risedronate)}

These agents are approved for prevention and treatment of osteoporosis, including steroid-induced osteoporosis, ${ }^{23}$ and osteoporosis in men. They improve BMD at spine and hip and reduce vertebral and non-vertebral fractures, including hip fractures, as shown in well-designed prospective studies. ${ }^{19,24,25}$ A once weekly dose of $70 \mathrm{mg}$ of alendronate is as effective as a daily dose of $10 \mathrm{mg}^{26}$

Selective estrogen receptor modulators (SERMs, e.g., raloxifene) Raloxifene is approved for prevention and treatment of osteoporosis in postmenopausal women. It causes a modest improvement in BMD and reduces the risk of vertebral fractures as shown in a major prospective study. ${ }^{27}$ Reduction of hip or other non-vertebral fractures has not yet been established in postmenopausal women. ${ }^{19}$
Raloxifene decreases the risk of estrogen receptor-positive invasive breast cancer although it has not been approved for such use. ${ }^{27}$

\section{Calcitonin}

Intranasal and subcutaneous calcitonin is approved for the treatment of osteoporosis in postmenopausal women. Calcitonin causes a modest improvement in BMD and reduces the risk of vertebral fractures in postmenopausal women with severe osteoporosis. ${ }^{27}$ Reduction of hip or nonvertebral fractures has not been established with this drug. Calcitonin has analgesic properties and can decrease the pain associated with acute vertebral fractures. As calcitonin causes only modest improvement in BMD and is expensive, its use must be limited to those who are unable to tolerate other agents, or those in whom other agents are contraindicated, or when pain control is an additional desired goal.

Table 4 is a summary of the effects on BMD and fracture risk of various pharmacological agents that are generally used for the prevention and treatment of osteoporosis in 


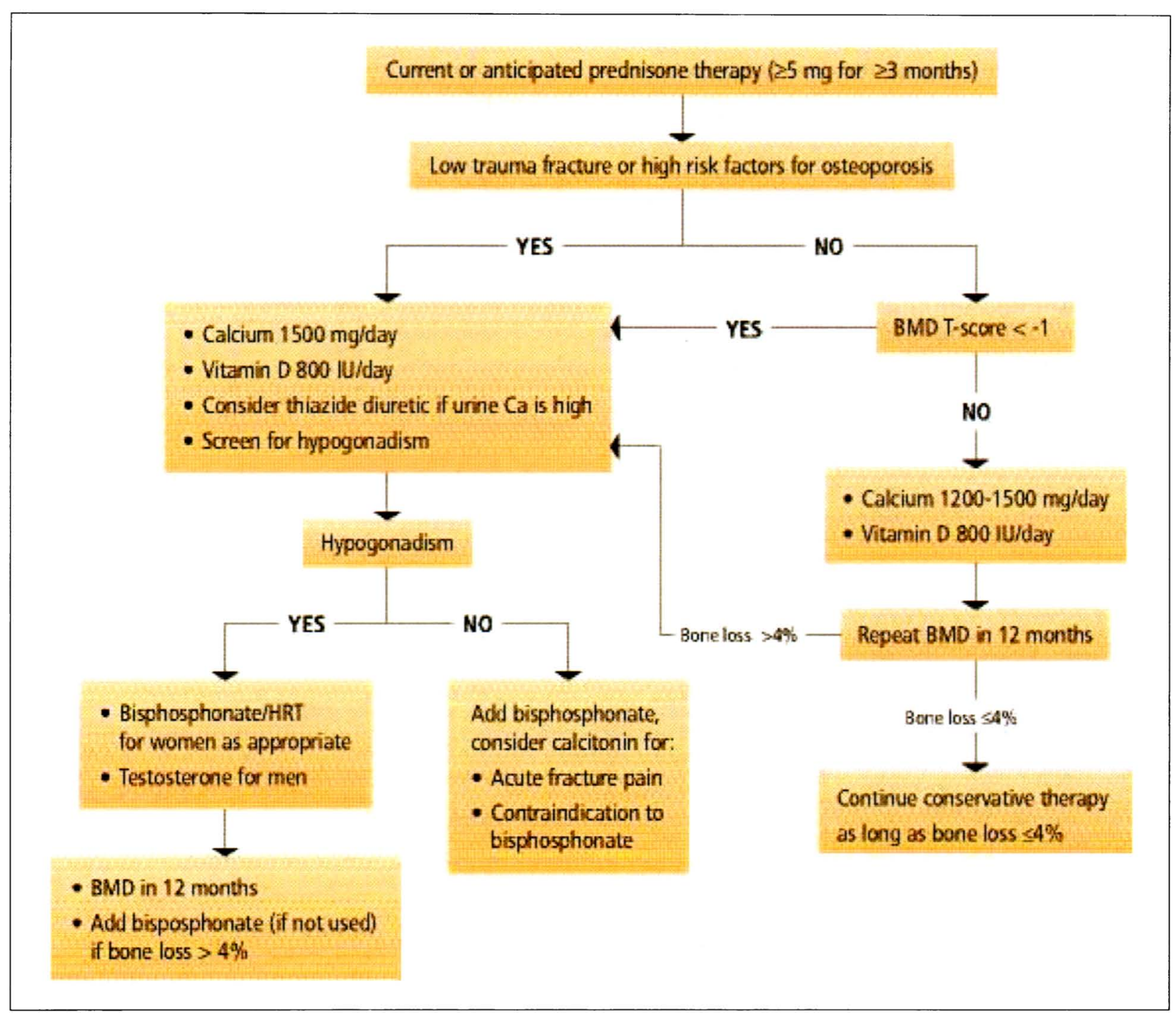

Figure 1. Recommendations of the Osteoporosis Working Group for prevention and treatment of glucorticoid-induced osteoporosis.

postmenopausal women, according to randomized controlled trials.

\section{Treatment recommendations}

In view of the lower fracture rates in our population, we might have to be more conservative in defining those who need potentially expensive pharmacological treatment. In addition to the level of BMD, fracture risk factors might help in defining a higher risk group that would be targeted for therapy. ${ }^{9}$ Based on BMD findings and fracture risk factors, the task force makes the recommendations shown in Table 5 .

\section{Premenopausal osteoporosis}

When osteoporosis is suspected in a premenopausal woman, based on a fragility fracture, clinical or radiologic findings, or multiple high-risk factors, a BMD measurement is indicated. If osteoporosis is present, every effort should be made to look for and correct secondary causes. Important secondary causes of low BMD in this age group include vitamin $\mathrm{D}$ deficiency, osteomalacia, primary and secondary hypogonadism (hyperprolactinemia, anorexia nervosa, premature ovarian failure), use of steroids, chemotherapy, and radiation. Management of these subjects includes an adequate intake of calcium and vitamin $\mathrm{D}$, and pharmacological therapy. Hypoestrogenic subjects could be treated with HRT. If not hypoestrogenic, or if there is further significant loss of bone mass while an HRT, consider therapy with bisphosphonates. Calcitonin may be used in case of intolerance to, or presence of a contraindication to bisphosphonates. 


\section{Osteoporosis in men}

Osteoporosis in men is not uncommon. Risk factors for osteoporosis in men are similar to those in women. When osteoporosis is suspected in men, a BMD measurement is indicated. The BMD T score seems to be a reliable indicator for predicting fractures in men as well. When osteoporosis is established, secondary causes should always be looked for. An adequate medical history, physical examination and appropriate investigations are warranted. Some of the important secondary causes for osteoporosis in men are alcoholism, tobacco smoking, hyperthyroidism, Cushing's disease, steroid use, multiple myeloma, hyperparathyroidism, use of heparin, and primary or secondary hypogonadism. Vitamin D deficiency should also be ruled out. The management of osteoporosis in men includes identifying and correcting underlying, secondary causes, ensuring an adequate calcium and vitamin $\mathrm{D}$ intake, if deficient, encouraging weight-bearing exercise, reducing or stopping tobacco smoking and alcohol intake, and pharmacologic therapy. If hypogonadism is present, treatment should consist of testosterone. If hypogonadism is not present, treatment should consist of a bisphosphonate, or calcitonin in the case of intolerance to, or in the presence of contraindications to bisphosphonates.

\section{Glucocorticoid-induced osteoporosis}

Our recommendations for the prevention and treatment of glucocorticoid-induced osteoporosis (Figure 1) are modified from the recommendations of the American College of Rheumatology. ${ }^{28}$

No financial support was provided for the taskforce.

\section{References}

1. Cooper C, Campion G, Melton U. Hip fractures in the elderly, a world wide projection. Osteoporos Int. 1992 Nov;2(6):285-289.

2. U.S. Preventive Services Task Force. Screening for osteoporosis in postmenopausal women: recommendations and rationale. Ann Intern Med. 2002;137: 526-528.

3. Writing Group for the Women's Health Initiative Investigators. Risks and Benefits of Estrogen Plus Progestin in Healthy Postmenopausal Women. JAMA. 2002;288:321-333.

4. Writing Group for the Heart and Estrogen/ progestin Replacement Study (HERS) Research Group, Randomized Trial of Estrogen Plus Progestin for Secondary Prevention of Coronary Heart Disease in Post Menopausal women. JAMA. 1998;280:605-618. 5. Cummings SR, Black DM, Thompson DE, et al. Effect of alendronate on risk of fracture in women with low bone density but without vertebral fractures: results from the Fracture Intervention Trial. JAMA. 1998; 261: 2189-2197

6. El-Douski M. Bone mineral density of the spine and femur in the normal Saudi population. Saudi Med J. 1995; 16:30-35

7. Baddoura R, Okais J, Awada H. Incidence of fractures after the age of 50 years in the Lebanese population and implications in terms of osteoporosis. Rev Epidemiol Sante Publique. 2001; 49(1): 27-32. 8. Al-Nuaim AR, Kremli M, Al-Nuaim M, and Sandkgi S. Incidence of proximal femur fracture in an urbanized community in Saudi Arabia. Calcif Tissue Int. 1999 56:536-538.

9. Black $D$, Steinbuch $M$, Palermo $L$, et al. An Assessment Tool for Predicting Risk in Postmenopausal Women. Osteoporosis Int. 2001: 12:519-528.

10. El-Desouki MI. Osteoporosis in postmenopausal Saudi women using dual X-ray bone densitometry. Saudi Med J. 1999:20(4):283-286.

11. Ghannam NN, Hammami MM, Bakheet SM, and Khan BA. Bone mineral density of the spine and femur in healthy Saudi females: Relation to vitamin D status, pregnancy, and lactation. Calci Tissue Int. 1999;65: 23-28.

12. Memon, et al. Incidence of hip fracture in Kuwait. Int J Epidemiol. 1998;27(5):860-865.

13. Hasserius R, Karlsson MK, Nilsson BE, et al Prevalent vertebral deformities predict increased mortality and increased fracture rate in both men and women, a 10-year population-based study of 598 individuals from the Swedish cohort in the European Vertebral Osteoporosis Study. Osteoporosis Int. 2003. Jan; 14(1):61-68

14. Braithwaite RS, Col NF, Wong JB. Estimating hip fracture morbidity, mortality, and costs. J Am Geriatr Soc. 2003;51(3):364-370.

15. Nelson HD, Helfand M, Woolf SH, Allan JD. Screening for postmenopausal osteoporosis: A review of the evidence for the US. Preventive Service Task Force. Ann Intern Med. 2002;137:529-541.

16. Wilkin TJ. Changing perceptions in osteoporosis. BMJ. 1999;318:862-864

17. Burger $H$, De Laet CEDH, Weel AEAM, Hofman A, Pols HAP. Added value of bone mineral density in hip fracture risk scores. Bone. 1999;25: 369

18. Reid IR, Ames RW, Evans MC, et al. Effect of Calcium Supplementation on Bone Loss in Postmenopausal Women. N Eng J Med. 1993;328:460.

19. Cranny A, Guyatt G, Griffith L. Summary of MetaAnalysis of Therapies for Postmenopausal Osteoporosis. Endocrine Rev. 2002;23(4):570-578.

20. Gillepsie WJ, Avenell A, Henry DA, et al. Vitamin D and vitamin $D$ analogues for preventing fractures associated with involutional and post-menopausal osteoporosis. Cochrane Database of Systematic Reviews. 2002:1. 21. Prince RL, Smith M, Dick IM. Prevention of postmenopausal osteoporosis. A comparative study of exercise, calcium supplementation, and hormone replacement therapy. N Eng J Med. 1991;325:1189.

22. Lufkin EG, Wahner HW, O'Fallen WM, et al. Treatment of postmenopausal osteoporosis with transdermal estrogen. Ann Intern Med. 1992;117:1-9.

23. Saag KG et al. Alendronate for the prevention and treatment of glucocorticoid-induced osteoporosis. Glucocorticoid-Induced Osteoporosis Intervention Study Group. N Eng J Med. 1998;339(5):292-299.

24. Black DM, Cummings SR, Karpf DB, et al. Randomised trial of effect of alendronate on risk of fracture in women with existing vertebral fractures. Lancet. 1996; 348:1535-1541.

25. Cranney A, Wells G, Willan A, et al. Meta-analysis of Alendronate for the Treatment of Postmenopausal Women. Endocrine Reviews. 2002; 23(4):508-516.

26. The Alendronate Once-Weekly Study Group Two year results of once-weekly administration of Alendronate $70 \mathrm{mg}$ for the treatment of postmenopausal osteoporosis. J Bone Miner Res. 2002;17:
1988-1996.

27. Ettinger B, Black DM, Mitlak BH, et al., for the Multiple Outcomes of Raloxifene Evaluation (MORE) Investigators. Reduction of vertebral fracture risk in postmenopausal women with osteoporosis treated with raloxifene. Results from a 3-year randomized clinical trial. JAMA. 1999;282:637-645.

28. Chestnut CH III, Silverman S, Adriano $K$, et al. A randomized trial of nasal spray salmon calcitonin in postmenopausal women with established osteoporosis: The PROOF study. Am J Med. 2000;109:267-276.

29. American College of Rheumatology Ad Hoc Committee on Glucocorticoid- Induced Osteoporosis. Arthritis and Rheumatism. 2001; 44(7):1496-1503.

\section{Other helpful guidelines and reviews}

Brown JP, Josse RG. Scientific Advisory Council of the Osteoporososis Society of Canada. 2002 Clinical practice guidelines for the diagnosis and management of osteoporosis in Canada. CMAJ. 2002:167 (Supplement 10): $51-534$

American Association of Clinical Endocrinologists. 2001 Medical Guidelines for Clinical Practice for the prevention and management of postmenopausal osteoporosis. Endocrine Practice. 2001;7(4):293- 311.

NIH Consensus Development Panel on Osteoporosis Prevention, Diagnosis, and Therapy, March 7-29, 2000: Highlights of Conference. South Med J. 2001; 94(6): 569-73

Royal College of Physicians and Bone and Tooth Society of Great Britain. Osteoporosis: Clinical guidelines for prevention and treatment. Royal College of Physicians, Online Publications: Working Party Reports, 2001.

Avioli LV. Epidemiology of Osteoporosis.In: Avioli LV, ed. Clinician's Manual on Osteoporosis. 2nd edition. London, Science Press, 1997

Kanis JA, Delmas P, Burckhardt P, Cooper C, Togerson D. Guidelines for diagnosis and management of osteoporosis. Osteoporosis Int. 1997;7:390-406.

World Health Organization. Assessment of fracture risk and its application to screening for postmenopausal women. WHO Technical Report Series 843. WHO. Geneva, 1994. 


\section{APPENDIX I}

Table A. Recommended calcium intake according to the National Institute Of Health, 1994.

\begin{tabular}{ll}
\hline Age & Recommended daily calcium intake $(\mathrm{mg})$ \\
\hline Birth to 6 months & 400 \\
6 months to 1 year & 600 \\
1 to 10 years & 800 \\
Teenagers & $1200-1500$ \\
Women & \\
$25-50$ years & 1000 \\
50 years with estrogen & 1000 \\
50 years without estrogen & 1500 \\
65 years & 1500 \\
Pregnant/ Lactating & 1200 \\
Men & \\
$25-65$ years & 1000 \\
$>65$ years & 1500
\end{tabular}

Table B. Calcium supplements available at King Faisal Specialist Hospital and Research Centre, and on the Saudi National Formulary.

\begin{tabular}{|c|c|c|c|}
\hline Name & $\begin{array}{c}\text { Type of Calcium } \\
\text { salt }\end{array}$ & $\begin{array}{c}\text { Amount of } \\
\text { Calcium salt per tablet }(\mathrm{mg})\end{array}$ & $\begin{array}{l}\text { Elemental Calcium per } \\
\text { tablet (mg) }\end{array}$ \\
\hline Ca Carbonate [Generic] & Carbonate & 650 & 260 \\
\hline $\begin{array}{l}\text { Ca Carbonate }+\mathrm{Mg} \text { Hydroxide }+\mathrm{Na} \\
\text { bicarbonate }\end{array}$ & Carbonate & 521 & 208 \\
\hline Ca Sandoz + Vitamin C Effervescent & $\begin{array}{c}\text { Carbonate } \\
\text { Lactate-gluconate }\end{array}$ & $\begin{array}{c}327 \\
1000\end{array}$ & $\begin{array}{c}130 \\
93 \\
+1000 \mathrm{mg} \mathrm{Na} \\
\text { bicarbonate } \\
+1000 \mathrm{mg} \text { vitamin } \mathrm{C}\end{array}$ \\
\hline Ca Sandoz Forte Effervescent & $\begin{array}{c}\text { Carbonate } \\
\text { Lactate-gluconate }\end{array}$ & $\begin{array}{c}300 \\
2940\end{array}$ & $\begin{array}{c}120 \\
273 \\
+1000 \mathrm{mg} \mathrm{Na} \\
\text { bicarbonate }\end{array}$ \\
\hline Caltrate 600 & Carbonate & 1500 & 600 \\
\hline Caltrate $600+$ Vitamin D & Carbonate & 1500 & $600+400$ IU vitamin D \\
\hline C-Vimin Ca Effervescent & Carbonate & 250 & $100+1000 \mathrm{mg}$ vitamin $C$ \\
\hline Cebion Ca Effervescent & Carbonate & 600 & $\begin{array}{l}240+400 \text { IU vitamin D3 } \\
+1000 \mathrm{mg} \text { vitamin C }\end{array}$ \\
\hline Kalcipos & Carbonate & 500 & 200 \\
\hline Kalcipos- D & Carbonate & 500 & $200+400 \mathrm{IU}$ vitamin D3 \\
\hline Os-Cal $250 \mathrm{mg}$ & Carbonate & 625 & 250 \\
\hline Os-Cal $500 \mathrm{mg}$ & Carbonate & 1250 & 500 \\
\hline Titralac Tablets & Carbonate & 420 & 168 \\
\hline \multirow[t]{2}{*}{ Calcefor effervescent } & Glycerophosphate & 578 & $225+1000 \mathrm{mg}$ vitamin $\mathrm{C}$ \\
\hline & & $\begin{array}{l}\text { Amount of Ca per } 5 \mathrm{ml} \\
\text { (mg) }\end{array}$ & $\begin{array}{l}\text { Elemental Ca per } 5 \mathrm{ml} \\
\qquad(\mathrm{mg})\end{array}$ \\
\hline Calciquid, Neo-Calglucon & Glubionate & 1,800 & 115 \\
\hline Ca gluconate & Gluconate & 650 & 58.5 \\
\hline Ca Sandoz syrup & $\begin{array}{l}\text { Glubionate } \\
\text { Lactobionate }\end{array}$ & $\begin{array}{c}1,090 \\
723\end{array}$ & 108 \\
\hline
\end{tabular}




\section{APPENDIX II}

Table C. Drugs available at King Faisal Specialist Hospital and Research Centre for prevention or treatment of osteoporosis: Dosage recommendations, and cost relative to the least expensive drug [Expressed as $\mathrm{X}$ ].

\begin{tabular}{|c|c|c|c|}
\hline Drugs & Dosage Form & Recommended Dose & $\begin{array}{l}\text { Approximate } \\
\text { Relative } \\
\text { Monthly Cost }\end{array}$ \\
\hline $\begin{array}{l}\text { Hormone Replacement Therapy } \\
\text { Conjugated equine estrogen (Premarin } ₫)\end{array}$ & Tablet: 0.3 mg, $0.625 \mathrm{mg}, 1.25 \mathrm{mg}$ & $0.625 \mathrm{mg} \mathrm{OD}$ & $\mathrm{x}$ \\
\hline $\begin{array}{l}\text { + Medroxyprogesterone acetate (Provera } ₫ \text { ) } \\
\text { for women with intact uterus }\end{array}$ & Tablet: $2.5 \mathrm{mg}, 10 \mathrm{mg}, 100 \mathrm{mg}$ & $2.5 \mathrm{mg} \mathrm{OD}$ & $1.5 x$ \\
\hline Estradiol valerate (Progynova $®$ ) & Tablet: $1 \mathrm{mg}, 2 \mathrm{mg}$ & $1-2 \mathrm{mg}$ QD & $4 X-5 x$ \\
\hline Cyclo-Progynova 2 mg (Progyluton $®)$ & $\begin{array}{l}11 \text { tablets of } 2 \mathrm{mg} \text { estradiol } \\
\text { valerate }[\mathrm{E}] \text {, and } 10 \text { tablets of } \\
2 \mathrm{mg} \text { estradiol valerate }[\mathrm{E}]+ \\
0.5 \mathrm{mg} \text { norgestrel }[\mathrm{N}]\end{array}$ & $\begin{array}{l}1 \text { tablet } \mathrm{E} \text { for } 11 \text { days, } \\
\text { followed by } 1 \text { tablet } \\
\mathrm{E}+\mathrm{N} \text { for } 10 \text { days. Leave } \\
\text { a tablet free interval of } 7 \\
\text { days, then repeat cycle. }\end{array}$ & $1.5 x$ \\
\hline Alendronate (Fosamax) & $\begin{array}{l}\text { Tablet: } 10 \mathrm{mg} \\
\text { Tablet: } 70 \mathrm{mg}\end{array}$ & $\begin{array}{l}10 \mathrm{mg} O D \\
70 \mathrm{mg} \text { once weekly }\end{array}$ & $\begin{array}{l}17 \times \\
19 \times\end{array}$ \\
\hline 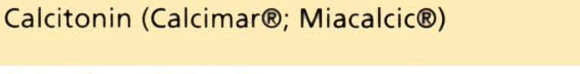 & $\begin{array}{l}\text { Intranasal spray } 100 \mathrm{IU} / \\
\text { metered dose }\end{array}$ & $200 \mathrm{IU}$ OD & $83 x$ \\
\hline Raloxifene (Evista®) & Tablet: 60 mg & $60 \mathrm{mg}$ OD & $20 x$ \\
\hline
\end{tabular}


Table D. Drugs available at King Faisal Specialist Hospital and Research Centre for prevention and treatment of osteoporosis.

\begin{tabular}{|c|c|c|c|c|}
\hline Drugs & Adverse Reactions & Drug interactions & Contra-indications & Precautions/Comments \\
\hline $\begin{array}{l}\text { Hormone } \\
\text { Replacement } \\
\text { Therapy }\end{array}$ & $\begin{array}{l}\text { Serious: Venous } \\
\text { thromboembolism, stroke, } \\
\text { coronary artery disease, breast } \\
\text { carcinoma, hepatic adenoma, } \\
\text { gallbladder disease, cholestatic } \\
\text { jaundice, pancreatitis, and } \\
\text { hypertension. Increased risk of } \\
\text { endometrial cancer, and possibly } \\
\text { ovarian cancer in women taking } \\
\text { unopposed estrogen } \\
\text { Common: menstrual } \\
\text { irregularities, breast tenderness, } \\
\text { nausea, bloating, abdominal } \\
\text { cramps, vomiting, headache, } \\
\text { dizziness, depression, peripheral } \\
\text { edema, weight changes, rash, } \\
\text { intolerance to contact lenses, } \\
\text { libido changes, increased } \\
\text { HDL, decreased LDL and } \\
\text { total cholesterol, increased } \\
\text { triglycerides }\end{array}$ & $\begin{array}{l}\text { Barbiturates, } \\
\text { steroids, insulin, } \\
\text { hypoglycemic } \\
\text { agents, } \\
\text { phenytoin, } \\
\text { rifampicin, } \\
\text { ursodiol }\end{array}$ & $\begin{array}{l}\text { Hypersensitivity } \\
\text { to drug/ class/ } \\
\text { component; } \\
\text { unexplained } \\
\text { vaginal bleeding; } \\
\text { thrombophlebitis, } \\
\text { thromboembolic } \\
\text { disorders or history } \\
\text { of thromboembolic } \\
\text { disease; coronary } \\
\text { artery disease; liver } \\
\text { disease; known } \\
\text { or suspected } \\
\text { pregnancy; } \\
\text { carcinoma of the } \\
\text { breast; and estrogen } \\
\text {-dependent tumors }\end{array}$ & $\begin{array}{l}\text { Use with caution in } \\
\text { patients with asthma, } \\
\text { diabetes, epilepsy, } \\
\text { migraine headache, or } \\
\text { heart, kidney, liver, or } \\
\text { gallbladder disease. } \\
\text { Daily combination of } 0.625 \\
\text { mg of conjugated } \\
\text { equine estrogen } \\
\text { and } 2.5 \text { mg of } \\
\text { medroxyprogesterone } \\
\text { acetate in healthy } \\
\text { postmenopausal } \\
\text { women (average } \\
\text { follow-up of } 5.2 \text { years) } \\
\text { was associated with } \\
\text { the following absolute } \\
\text { excess risks per } 10,000 \\
\text { person years: } 7 \text { heart } \\
\text { attacks, } 8 \text { strokes, } 18 \\
\text { blood clots, and } 8 \\
\text { breast cancers ( } 39 \text { ). }\end{array}$ \\
\hline $\begin{array}{l}\text { Alendronate } \\
\text { (Fosamax) }\end{array}$ & $\begin{array}{l}\text { Serious: Esophagitis, gastritis } \\
\text { Common: abdominal pain, } \\
\text { myalgias, arthralgia, back } \\
\text { pain, nausea, dyspepsia, } \\
\text { constipation, diarrhea, } \\
\text { flatulence, headache, acid } \\
\text { reflux, vomiting, dysphagia, } \\
\text { abdominal distension, chest } \\
\text { pain, peripheral edema, flu- } \\
\text { like symptoms, esophageal } \\
\text { ulcer }\end{array}$ & $\begin{array}{l}\text { Antacids, calcium } \\
\text { salts, and } \\
\text { multivitamins } \\
\text { with minerals } \\
\text { may decrease } \\
\text { absorption of } \\
\text { bisphosphonates }\end{array}$ & $\begin{array}{l}\text { Hypersensitivity } \\
\text { to drug/ class/ } \\
\text { component; } \\
\text { hypocalcemia; } \\
\text { abnormalities of the } \\
\text { esophagus which } \\
\text { delay esophageal } \\
\text { emptying (stricture, } \\
\text { achalasia); inability } \\
\text { to stand or sit } \\
\text { upright for at least } \\
30 \text { minutes; Gl } \\
\text { bleeding; severe } \\
\text { renal dysfunction }\end{array}$ & $\begin{array}{l}\text { Use with caution for } \\
\text { patients with moderate } \\
\text { renal insufficiency, } \\
\text { ulcers, heartburn, } \\
\text { hypoparathyroidism, } \\
\text { pregnancy, and breast } \\
\text { feeding. Correct } \\
\text { hypocalcemia and } \\
\text { disturbances of mineral } \\
\text { metabolism before } \\
\text { initiating alendronate }\end{array}$ \\
\hline $\begin{array}{l}\text { Calcitonin } \\
\text { (Calcimar, } \\
\text { Miacalcic) }\end{array}$ & $\begin{array}{l}\text { Nasal irritation, rhinitis, back } \\
\text { pain, arthralgias, epistaxis, } \\
\text { headache, sinusitis, dizziness, } \\
\text { nausea, vomiting, flushing, } \\
\text { rash }\end{array}$ & $\begin{array}{l}\text { Plicamycin may } \\
\text { enhance } \\
\text { hypocalcemic } \\
\text { effect of } \\
\text { calcitonin. }\end{array}$ & $\begin{array}{l}\text { Hypersensitivity to } \\
\text { the drug/class/ } \\
\text { components [salmon } \\
\text { protein or gelatine } \\
\text { diluents] }\end{array}$ & $\begin{array}{l}\text { A skin test should be } \\
\text { performed prior to } \\
\text { initiating therapy of } \\
\text { calcitonin salmon; } \\
\text { Use with caution in } \\
\text { pregnant women }\end{array}$ \\
\hline $\begin{array}{l}\text { Raloxifene } \\
\text { (Evista) }\end{array}$ & $\begin{array}{l}\text { Serious: Deep vein thrombosis, } \\
\text { pulmonary embolism, retinal } \\
\text { vein thrombosis. } \\
\text { Common: Hot flashes, flu-like } \\
\text { symptoms, arthralgias, } \\
\text { sinusitis, nausea, weight } \\
\text { gain, pharyngitis, depression, } \\
\text { cough, leg cramps, rash, } \\
\text { insomnia, dyspepsia }\end{array}$ & $\begin{array}{l}\text { Cholestyramine } \\
\text { reduces the } \\
\text { absorption } \\
\text { of raloxifene. } \\
\text { Raloxifene } \\
\text { should not be } \\
\text { used with high } \\
\text { protein bound } \\
\text { drugs. }\end{array}$ & $\begin{array}{l}\text { Hypersensitivity } \\
\text { to drug, class/ } \\
\text { component; } \\
\text { pregnancy or } \\
\text { planned pregnancy; } \\
\text { deep vein } \\
\text { thrombosis, or } \\
\text { history of deep vein } \\
\text { thrombosis }\end{array}$ & $\begin{array}{l}\text { Patients with cardiovascular } \\
\text { disease, history of } \\
\text { cervical/uterine } \\
\text { carcinoma, or renal/ } \\
\text { hepatic insufficiency; } \\
\text { not to be used } \\
\text { concurrently with } \\
\text { estrogens }\end{array}$ \\
\hline
\end{tabular}

